Portland State University

PDXScholar

$5-5-1994$

\title{
A Study of the Meaning Found in the References to Space in Selected Plays of Athol Fugard
}

Heather Halm Stueve

Portland State University

Follow this and additional works at: https://pdxscholar.library.pdx.edu/open_access_etds

Part of the Theatre and Performance Studies Commons Let us know how access to this document benefits you.

\section{Recommended Citation}

Stueve, Heather Halm, "A Study of the Meaning Found in the References to Space in Selected Plays of Athol Fugard" (1994). Dissertations and Theses. Paper 4778.

https://doi.org/10.15760/etd.6662

This Thesis is brought to you for free and open access. It has been accepted for inclusion in Dissertations and Theses by an authorized administrator of PDXScholar. Please contact us if we can make this document more accessible: pdxscholar@pdx.edu. 
THESIS APPROVAL

The abstract and thesis of Heather Halm Stueve for the Master of Arts in Theater Arts were presented May 5, 1994, and accepted by the thesis committee and the department.

COMMITTEE APPROVALS :

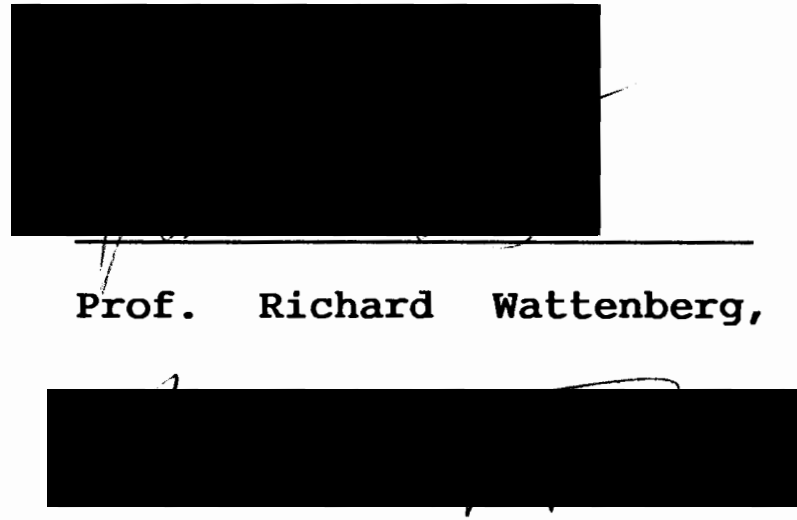

Prof. William Tate

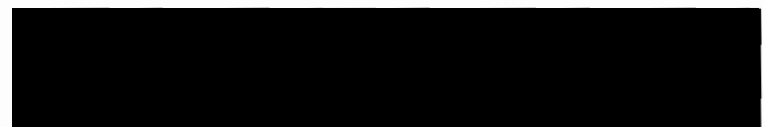

Prof. Christine Thompson

DEPARTMENT APPROVAL :

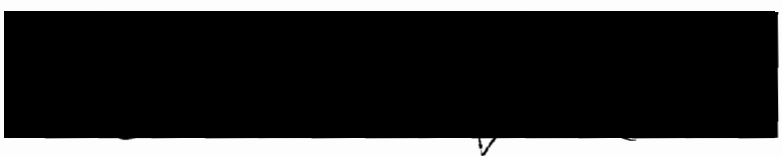

Prof. William Tate, Chair Department of Theater Arts

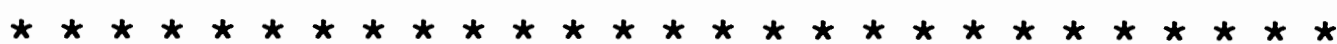

ACCEPTED FOR PORTLAND STATE UNIVERSITY BY THE LIBRARY by on $\bar{x}$ lesenes 1994 


\section{ABSTRACT}

An abstract of the thesis of Heather Halm stueve for the Master of Arts in Theater Arts presented May 5, 1994.

Title: A study of the Meaning Found in the References to space in selected Plays of Athol Fugard.

The south African playwright Athol Fugard often explores the problems which apartheid has created within his society -problems ranging from the racial and societal to the spiritual. He seems to communicate his thoughts about these issues through many direct references to space. This study investigates the meanings these spaces communicate.

Four plays were chosen as representative of Fugard's subject matter (covering both white and non-white society) and career: Blood Knot (1963), People are Living There (1970), The Road to Mecca (1985), and My Children, My Africa (1990). Then three steps were carefully followed. First, each reference to space was identified and categorized using Keir Elam's and susanne Langer's definition of "virtual space" as guide to the establishment of categories. Three categories were established: virtual space (that which is immediately visible to the audience), extended-virtual space (the off stage world which is real to the characters but unseen by the audience), and imaginary space (that which the characters project on or into the world around them). second, patterns and relationships among the spaces were identified (using 
Kenneth Burke's and Mary Mccarthy's methodology of image clusters and dramatic alignments). Third and finally, the meaning of these patterns was explored, often using Edward Hall's science of proxemics to facilitate understanding. There is considerable similarity and continuity from play to play in the use of space. Fugard often employs references to extended-virtual space to communicate the many ills which have arisen in south African society. He also typically includes a virtual space or spaces which provide a safe haven from those ills. In addition, he almost always uses reference to imaginary space or spaces to communicate the hope for the future of freedom for all of south Africa's people.

Ideally, the recognition of the spaces in Fugard's work should be actively, and knowingly, articulated in any production of his plays. This study provides a methodology for exploring these spaces and an indication of what many of the spaces mean. 


\title{
A BTUDY OF THE MEANING FOUND IN THE REFERENCES TO SPACE IN SELECTED PLAYS OF ATHOL FUGARD
}

\section{by}

HEATHER HALM STUEVE

A thesis submitted in partial fulfillment of the requirements for the degree of

\author{
MASTER OF ARTS \\ in \\ THEATRE ARTS
}

\section{Portland state University 1994}


TABLE OF CONTENTS

CHAPTER

PAGE

I INTRODUCTION: Goals and Methodology . . . 1

What to Look for and Why . . . . . . 1

How and Where to Look . . . . . . . . 3

II BLOOD KNOT - . . . . . . . . . . . . . . 16

Identification and Classification . . 17

Spatial Alignments . . . . . . . . 24

Meaning . . . . . . . . . . . 25

III PEOPLE ARE LIVING THERE . . . . . . . . . 30

Identification and Classification . . 31

Spatial Alignments . . . . . . . 37

Meaning . . . . . . . . . . . . 39

IV THE ROAD TO MECCA . . . . . . . . . . . 42

Identification and Classification . . 43

Spatial Alignments . . . . . . . 50

Meaning . . . . . . . . . . . . 52

V MY CHILDREN, MY AFRICA . . . . . . . . . 56

Identification and Classification . . 57

Spatial Alignments . . . . . . . . 62

Meaning - . . . . . . . . . . . 65

VI CONCLUSION . . . . . . . . . . . . . . 70

A SELECTED BIBLIOGRAPHY - . . . . . . . . . . . . . 74 
CHAPTER I

GOALS AND METHODOLOGY

\section{What to Look for and why}

I don't think I will ever forget the extended conversation the three of us had in that compartment, watching South Africa slip past the window. All that is good and bad--and worse than bad, rotten and wrong--with the white man in [South Africa]--his generosity and incredible meanness of spirit, his shrinking heart, his wonderful and simple humor--all of it, as never before in one incident of my life, in our second-class compartment broke loose from our hearts (Fugard $1990 a, 84$ ).

This quote comes from the Notebooks of Athol Fugard, a personal journal published in 1983. The passage was written as Fugard rode a train through the countryside, and expresses his realization that the essence of the "white man" who lives in the vast country of South Africa could be encompassed within the small, tight space of a single compartment of a train. Perhaps the image spoke to Fugard of what he sees as the "small" spirit of the white man in contrast to the "large" potential of the South Africa outside the train window. Fugard is often drawn to such spatial images -- images of large spaces in comparison and contrast to small, tight spaces -- and interested in the meaning such images might 
communicate. Throughout his notebooks, novels, and other writings, Fugard sees and uses spatial references to explore, communicate and understand his thoughts.

Space is also central to Fugard's concept of the theatrical experience. Even in his description of theatre, Fugard uses a spatial reference: ". . the actor and the stage, the actor on the stage. Around him is space, to be filled and defined by movement and gesture. . ." (Walder 1985, 12). Of course, nearly every playwright, director, or actor might make the same statement. But there lies in Athol Fugard's understanding of spaces a sense that all the kinds of spatial references -- from the location of the smallest prop to the wide evocations of space in a character's imagination - function as images which are intended to communicate meaning. This is not surprising, considering the fact that space can be such a powerful image.

This study will explore the meaning the spatial images of his plays are intended to communicate and whether they "concentrate the whole feeling"1 of the action of the play. For the purpose of this study, spatial images will include metaphors employing space found in the dialogue, visual pictures of space created by the characters, and the

1 This phrase comes from an essay by George Whalley entitled "From Symbol and Myth." He writes, "[Images] assume a focal position as an object of contemplation. . . and in the developing event of reality the focal image, the symbol, sustains and concentrates the whole feeling of the event." $(1953,349-350)$ 
references to space appearing in stage directions as established by Fugard. All of these references to space must be considered in order to encompass the sheer volume of references and the range of manipulation of spatial images in Fugard's body of work. He is extremely specific about spatial images in his plays. It is the purpose of this study to investigate the communication of these spatial images.

This purpose addresses what Kenneth Burke, the renowned critic, called the first step "implicit in a perspective... what to look for and why." According to Burke, "how, when, and where to look for it" $(1967,68)$ is the second kind of question implicit in a perspective. The rest of this chapter will attempt to answer this question in order to establish a workable methodology. In this endeavor, guidance will be found in the analytical work of semiotician Keir Elam who argues that space is a means of communication which can be understood and used in the realm of theatre. Additional direction will be found in the critical works of Kenneth Burke and Mary McCarthy, both of whom investigate image as a source of meaning .

\section{How and where to Look}

This study will examine spatial images in the texts of 
Fugard's plays in order to discover the meaning these images suggest. The idea of exploring dramatic pieces through the use of the delineation of space is not inconsistent with the nature of theatre activity. playwrights have provided "worlds" which are specific in spatial terms to the needs of the character or the theme of the work. Directors have been accustomed to defining the space in a play by the placement of actors in that space. Set designers strive to represent the mood or theme of a play through the creation of a specific space. In Fugard's case, he is often involved in all three -in the writing, directing, and designing. ${ }^{2}$ And in all three, he manipulates spatial images. In a passage which could describe Fugard's perspective, Elam writes, "However significant the temporal structure of the performance, there is good reason for arguing that the theatrical text is defined and perceived above all in spatial terms" $(1980,56)$. But how can text be defined by space? The science of proxemics can help us understand how to interpret space.

The premise of proxemic science is, as stated by its founder Edward T. Hall, that "space speaks" (1959, 187). In other words, humans communicate through their understanding and use of space. To illustrate this concept, an example can be gleaned from Hall himself. Hall states, "Our concept makes

2 Indeed, Fugard has usually been so involved with his plays that he has often directed and acted in the original productions of his plays, as result taking control of how the images of space are articulated through design and communicated through use. 
use of the edges of things." By this statement, he explores the fact that one space can be vastly different from another, and that difference is established by an "edge." we often have doorways which separate our living rooms from our dining rooms -- doorways which establish an edge between two spaces with very different purposes. This is but one example of the parameter of proxemics. As another, consider an American girl as she eventually reaches an age, probably around thirteen, when her room truly becomes her territory. The teenager immediately feels threatened if anyone trespasses into her territory without permission. She uses her territory to communicate her growing sense of independence and individualism. Such territoriality exists in every culture, and often defines the identity of self. Proxemics also deals with distinctions like those between intimate space (the space established as private and personal) and public space (the space open to and filled by the general masses), as well as concepts such as the reluctant or enthusiastic use of all these spaces, etcetera. (Hall 1959, 187-209).

Keir Elam, in his book The Semiotics of Theatre and Drama, embraces proxemics as a possible tool for theatre artisans as they attempt to communicate to the audience. As Elam defines proxemics:

This science is founded on the well-tested hypothesis that man's use of space in his architectural, domestic, urban, workplace, and aesthetic activities is neither casual nor merely functional but represents a semiotically loaded choice subject to powerful rules which generate a 
range of connotative units. $(1980,62)$

Elam believes that this new science is not restricted to analyzing elements of everyday life, but that the intrinsic and purposeful understanding of proxemics affects both the playwright in his creation of fictitious space in the script and the director in his shaping of space on stage. ${ }^{3}$

Proxemics, however, was developed specifically to investigate the use of space in daily life. Elam proposes to use proxemics to study space in the field of theatre, but to do so requires a clear understanding of how space is defined in theatrical terms. Elam provides a clear definition as to the type of space he considers essential by expanding upon the work of a renowned critical essayist:

Performance spatiality is not limited, however, to the actual interstitial areas marked out by fixed, semi-fixed, and dynamic theatrical components. Any representation, if it is successfully to evoke a fictional dramatic scene will create what suranne Langer defines as virtual space -- that is, an illusionistic "intangible image". . . $(1980,67$, emphasis added)

Elam's principle source, suzanne Langer, is quite specific about the "spaces" artists create. From her perspective, actual space is the actual form with which an artist works $(1953,74)$. In the realm of theatre, this would suggest the theatre building itself and the stage filled with

3 Elam is not alone in his high regard for the importance of spatial relationships in the understanding of drama. Andre Helbo, in his book Theory of Performing Arts, also places the study of proxemics among the three relatively new areas of research which are note-worthy $(1987,39)$. 
the lumber, paint and lighting used to create the set. Virtual space is something different. In Ms. Langer's own words:

virtual space, being entirely independent and not a local area in actual space, is a self-contained, total system. Whether it be 2-dimensional, or three, it is continuous in all its possible directions. . . (Langer 1953, 75)

Virtual space is a rather abstract idea; it is the result of the shaping of actual space. The manipulation of actual space leads us to believe in the existence of a virtual space. Langer refers to visual arts critic Hildebrand in defining virtual space as "the space of which we are clearly conscious when we attend to the distance plane... [this space lies BEHIND [ the distance plane]... [This] space is conceived as a penetration into the distance" (Langer, 60). Thus an actual, physical set on a theatrical stage is used to "delimit the 'world' in which virtual action exists" (Langer, 322). For example, an actual set made of wood and canvas and filled with chairs and other furniture becomes a room to the audience -- a room whose walls, furnishings, and floors belong to the world of the characters.

As Elam expanded upon the work of Langer, so this study will expand upon the work of Elam. Fugard seems to manipulate space into categories beyond simple "virtual." In order to derive full meaning from the playwright's many spatial images, additional categories of space will be established. Specifically, Langer's virtual space will be divided into two 
types of space ("virtual" and "extended-virtual") -- and a space categorized as "imaginary" will be added.

The virtual spaces, or "illusionistic intangible images", Fugard evokes are of two forms. The first type will simply be titled "virtual" and refers to the illusion of reality which is created onstage within the limitations of the set. This is Langer and Elam's virtual space, in the strictest sense. This virtual space incorporates all the elements of a set, including the actual furnishing, decor, and smaller props located on stage--for once onstage and viewed in the context of a play, the actual items become part of the virtual world. Thus, in this study, we will often describe a virtual space by also referring to some of the actual elements which are employed.

The second type of virtual space will be termed "extended-virtual", meaning that unseen world which lies beyond the immediately visible world represented on stage. This space is usually not present to the audience, but quite real to the characters. The characters inform the audience about the extended-virtual space beyond the virtual space established by the set. Consider the spaces created in People Are Living There. The kitchen created by the artifice of set design becomes a virtual space. The city streets which lie beyond the kitchen door are extended-virtual; real to the character of Milly, but unseen by the audience.

There is another type of space created by Fugard which 
will be called "imaginary" -- a space which is projected by both the audience and the characters onto the virtual space through their imaginations. At times this imaginary space becomes so vivid that the characters "play" in it -- resulting in a metatheatre experience for the audience. It's rather like the sense of space created by children when they play in an entire "forest" in their own backyard. An example cited in the body of this work is the "game in the park" played by the brothers in Blood knot. The park is not physically visible to either the viewers or the brothers, but it eventually becomes quite real in the imaginations of all. Thus, the three types of space in Fugard's works are: 1) virtual, 2) extendedvirtual, and 3) imaginary.

But the use of these three categories of space alone is not informative about the meaning of these spaces. Categorizing must lead to understanding. Categorizing will establish some sense of order among images, revealing patterns which exist or images which are repeated time after time. It is the repetition of patterns which often lead to an audience's comprehension of the images in a piece of work. Mary McCarthy has explored patterns of images as a means of interpretation. Her method of finding meaning is simple. She identifies key images. Ms. McCarthy herself states her method of finding patterns, and therefore meaning, quite clearly:

The images of a novel or a story belong, as it were, to a family, very closely knit and inseparable from each other; the parent " idea" of a story or a novel generates events 
and images all bearing a strong family resemblance. And to understand a story. . you must look for the parent "idea" which is usually in plain view, if you read quite carefully and literally what the author says. (McCarthy essay in Hall 1965, 347)

Mccarthy's ideas apply to Fugard, for he appears to have used a set of images (McCarthy's "family of images") throughout the three categories of spaces which indicate possible meaning (McCarthy's "parent idea"). Burke also recognizes, and in fact emphasizes, the importance of a family of images, or as he terms them, "image clusters." "A 'house' in a poem can become a 'house plus' as it does proxy for the other ingredients that cluster about it" $(1967,27)$. These clusters can lead directly to meaning, for they can help us see the patterns which exist among or within the references to virtual, extended-virtual, and imaginary spaces. For example, in Fugard's 1969 play Boesman and Lena, repeated virtual images such as the circular movements through the countryside presented on stage, the shacks, and the corrugated iron shanty next to the fire, and repeated extended-virtual images of the muddy swartkops and the lists of towns, lead to an understanding of the world of people like Boesman and Lena. This becomes especially apparent as those clusters encompass and even cross the three categories of space, eventually leading to a central idea. In additon, as clusters of virtual images suggest the same meaning within a play, that meaning will transfer to the virtual clusters in Fugard's other plays. Thus creating a pattern which exists from play to play. 
Burke suggests that another of the primary patterns to be discovered is "dramatic alignment" (1967, 69). Dramatic alignment simply refers to the juxtaposition of contrary images. A familiar example of images in dramatic alignment might be taken from Tennessee William's The Glass Menagerie. The image of the gentleman caller is pitted against the dominant image of the wayward father who appears in the form of a portrait hanging on the living room wall. These are two images in direct juxtaposition, representing the difference between what is desired and what is reality in Amanda's (and Laura's) life. Another example can be found in Fugard's The Road to Mecca. Consider this passage: "This is my world and I have banished darkness from it. . . I can't reduce my world to a few ornaments in a small room in an old-age home" (1985, 99). A large space ("my world") is aligned against a small one ("a small room"), creating a tension which is an accurate reflection of the action and theme of the play (see chapter four of this study). Similar alignments will be found among many of Athol Fugard's spatial images. Such contrasts as virtual space vs. imagined space and virtual vs. extendedvirtual space will become clear as a result of the ways in which these spaces embody certain concepts drawn from proxemics: private space vs. public space, accessible space vs. restricted space, space with sharp edges vs. undefined space, etc. These contradictory alignments will provide clues as to what these spaces mean. And, once again, it will be 
possible to see similarities in meaning from play to play.

During the course of this study, then, spatial images will be examined, and through the patterns of these images, meaning will be discovered. Three steps will be followed. The first is to identify and categorize the references to virtual, extended-virtual, and imaginary space within Fugard's plays. This step was accomplished during the research for this study and will be summarized in each of the following chapters. The second will be to define the relationships or patterns which exist among the spatial images as they fall into these three categories. The third, then, will be to explore the meanings of these patterns, often turning to the science of proxemics to understand the reasons the various spaces are included in Fugard's works.

Dennis Walder, in his book Athol Fugard, states that "Fugard's plays are all, on some level, more or less explicitly, a protest about the quality of life in south Africa" (1985, 18). In this regard, the spatial images in Fugard's plays communicate the reality of life as experienced by his South African characters. Indeed, reviewer David Coplan confirmed this fact as he wrote about The Blood Knot, "Fugard's claustrophobic dramas reach both outward to universal human dilemmas and inward to south Africa's agonistic, all too human heart" (Gray 1991, 22). In order to substantiate this perception, four of his plays will be studied in depth; the four were chosen because of their 
critical acclaim and the examples they provide of Fugard as a writer over the years. Blood knot, written in the early sixties, was one of Fugard's earliest successes. People are Living There (1970) and The Road to Mecca (1985) will account for the middle years of his career ${ }^{4}$, and My Children, My Africa, which opened on Broadway in 1990, will represent his most recent works.

These four were also chosen because they represent the two major areas of South African life which Fugard most often considers: the quality of life among the "Coloured" segment of South African society and the isolation in life which occurs among many South African "poor whites" (Walder 1985, 6). 5 Blood Knot and My Children, My Africa, will serve as representative of Fugard's plays focusing on the "coloured" race. Similarly, the plays people Are Living There and The Road to Mecca explore the lives of "poor white" in South

4 During many of the years between 1970 and 1985 Fugard was experimenting with improvisational and collaborative ways to develop a script. As these methods do not allow Fugard sole control over content, they will not be considered in the course of this study. It is interesting to note, however, that the interpretations established in this paper are in Fugard's collaborative work as well.

5 It should be understood by anyone reading this thesis that South Africans recognize three primary ethnic groups in their country: the tribal blacks, the "coloured" blacks, and the Afrikaaners. Most of the history of apartheid actually involves the conflicts between the Afrikaaners and the "coloureds" which resulted from generations of white oppression and inter-mixing. As Walder writes, "Fugard's [one little corner of the world] is the eastern Cape region of South Africa, among the 'poor Whites', the 'Coloureds' and, occasionally, members of the subject African majority." (1985, 6) 
African society. The choice of these four plays should provide a glimpse into Fugard's insights into South African society and the way in which he communicates these insights through spatial images.

Although to date no thorough study of the meanings of Fugard's spaces has been undertaken, there is a strong precedent for such a study of an author's intentional use of space as image. Literary critic Mark Schorer explored the delineations of space as they were used by Sinclair Lewis in such novels as Main street. He says of Lewis, "What Lewis loved so passionately about America was its potentiality for and constant expression of a wide, casually human freedom" (1972, 302). While Lewis loved America's expansiveness, Schorer notes that his predominant spatial images are of small, limiting spaces, such as Main street, Gopher Prairie, Minnesota. "The point perhaps, is that in his novels it was easier for [Lewis] to dramatize the repressions than it was to dramatically affirm the freedoms. . " (1972, 303). There is a parallel between this realization of schorer and the purpose of this study. Like Sinclair Lewis, Athol Fugard quite obviously loves his country of South Africa. He loves its peoples and its potential. But, Fugard can unfortunately find little to affirm in the way of South African freedom. He has, for instance, built a reputation on his outspoken views against apartheid. Thus, like Lewis, Fugard perhaps finds it much easier to show the repressions, the limitations 
experienced by the people he loves. Perhaps this is why, like Sinclair Lewis, Fugard seems to use small, tight spaces aligned against wide, open spaces as representative of his characters or his themes. The exploration of Fugard's spatial images shall reveal whether this is true. 
CHAPTER II

\section{BLOOD KNOT}

The Blood Knot began, and performances still begin, as an evocation of place (Walder 1985, 51).

Athol Fugard's first success as a playwright was the 1963 production of Blood Knot. It is a powerful play which explores the tensions and bonds between two brothers living in a one-room shack in a "location" set aside for members of the "coloured" segment of South African society. Morris ("Morrie"), the elder brother, is light-skinned, which has allowed him to "pass" for white at times. Zachariah is darkskinned, and it is in his room that the action of the play takes place. As Dennis Walder, in his book Athol Fugard, notes above, this place is an important element in this play. Place and the space surrounding place are sources of meaning for the play. To discover this meaning, the first step is to identify and describe the types of spaces used by Fugard in this play. 


\section{Identification and Classification}

\section{Virtual Spaces}

The virtual space where the play's action takes place is the brother's one-room shack. It is essential that one have a clear picture of the actual set which creates the virtual presence of the shack as it is described by Fugard in his stage directions.

All the action takes place in a one-room shack in the Non-white location of Korsten, near Port Elizabeth, South Africa. The walls are a patchwork of scraps of corrugated iron, packing-case wood, flattened cardboard boxes and old hessian bags. There is one door, one window (no curtains), two beds, a table, and two chairs. Also in evidence is a cupboard of sorts with an oil stove, a kettle and a few pots. The shack is tidy and swept, but this only enhances the poverty of its furnishings. (7)

This is a small, tight, intimate space -- startlingly tiny for the home of two men. It might be surprising for the audience that not only do two characters live in this set, but the entire action of the play takes place within its patchwork walls. This space has only one door which provides access to the larger outside, only one window which allows a glimpse of the lake (an image which will be explored later), and barely enough furnishing for two men. It is a meager space. But it 
is important to note that Morrie takes deep pride in the condition of this space, making the shack his, and his brother's, territory. In spite of the fact that this is rightfully zach's property, Morris claims it as both of theirs, for they are blood brothers and what belongs to one belongs to the other. Therefore, Morrie fills this space, uses it, carefully.

Lying on his bed, the one with the shelf, and staring up at the ceiling is MORRIS. After a few seconds he stands up on the bed, looks at the alarm clock and then lies down again in the same position. Time passes. The alarm rings and MORRIS jumps purposefully to his feet. He knows exactly what he is going to do. First, he winds and resets the clock, then lights the oil stove and puts on a kettle of water. Next, he places an enamel washbasin on the floor in front of the other bed and lays out a towel. He feels the kettle on the stove and then goes to the door and looks out. Nothing. He wanders aimlessly around the room for a few more seconds, pausing at the window for a long look at whatever lies beyond. Eventually he is back at the door again and, after a short wait, he sees someone coming. . . (9)

This is a poor place, but it is a safe place. Morrie has experienced life outside the shack, but he chose to return to it. It has become an asylum for him. Once Morris comes back to his brother Zachariah, he seems determined to rarely leave the room. "zACHARIAH. You never want to go out, Morrie. MORRIS. So I don't want to go out" (14). The virtual space is a haven, especially for Morris.

In describing the shack, Fugard refers to a window and a door. He is not specific in his stage direction as to the view seen from either of them. In this regard, the window is 
especially interesting because it is curtainless. This window establishes access for the audience and Morris to the outside world. This window becomes a constant reminder for the characters and the audience of the tension between the world surrounding the haven of the shack and the life in the shack itself.

\section{Extended-Virtual Spaces}

The extended-virtual spaces in Blood Knot include:

* the Non-white location of Korsten, lying just outside the walls of the shack

* the lake, rotten and dying

* the road that Morrie took which led him back to Korsten

* Oudtshoorn, a white town where Ethel lives

* the park where Zach works everyday

The geographical setting for this play is the extendedvirtual space of Korsten. Athol Fugard describes the location he used as the background for this play in the following entry in his notebook:

Korsten: The Berry's Corner bus, then up the road past the big motor assembly and rubber factories. Turn right down a dirt road -- badly potholed, full of stones, donkeys wandering loose, Chinese and Indian grocery shops -- down this road until you come to the lake. Dumping ground for waste products from the factories. Terrible smell. On the far side, like a scab, Korsten location. A collection of shanties, pondoks, lean-to's. No streets, names, or numbers. A world where anything goes. . In one of the shacks the two brothers -- Morrie and Zach. . . (1990a, 53)

Fugard has created a vivid picture of the decay and poverty of the location. Korsten represents all that is rotten with the 
locations of South Africa. It is truly a completely undesirable place in which to live. ${ }^{6}$

Eventually in the play, the township Oudtshoorn is also described as a place from which "bad times" come (51). Oudtshoorn represents the white towns -- the source of most of the problems for the "coloured" man in South Africa. As Morris says, "[Oudtshoorn's] not far enough for safety's sake" (39). Both the location and the township are highly restrictive spaces -- the movements of the "coloureds" such as Morris and zach are carefully controlled by the rules and regulations imposed by the white government. The resulting squalor of the area is further described by Morris towards the end of the play as he considers the lake edging the location: "It's the mystery of my life, that lake. I mean. . . it looks dead, doesn't it? If ever there was a piece of water that looks dead and done for, that's what I'm looking at now" (84). The reality of these extended-virtual spaces suggest an extremely oppressive environment.

This meaning is supported by the way some of these images cluster: the location and the lake. One cannot be pictured without the other. In this cluster of images surrounding the location, the central focus seems to be the decay, the dark

6It is interesting to note the South African societal consensus which resulted in naming the area set apart for the non-whites with a spatial term: "location." Perhaps this is a strong hint as to why Fugard is intuitively aware of spatial images. It may be a societal tendency to focus on space as a definition of reality. 
reality of the brothers' existence. Morris explains his feelings about the location and the lake below:

MORRIS. - . We're going to pack our things in something and get to hell and gone out of here. You say I don't want to go out? My reply is I do, but I want to get right out. You think I like it here more than you? You should have been here this afternoon, Zach. The wind was blowing again. Coming this way it was, right across the lake. You should have smelt it, man. I'm telling you that water has gone bad. Really rotten! And what about the factories there on the other side? Hey? Lavatories all around us? They've left no room for a man to breathe. (17)

Every thing is rotten -- the lake and the location. It is unavoidable and incontrovertible: This is a terrible reality in which to live.

There is one final extended-virtual space which should be explained: the park where Zach works. This is the same park which is invoked as an imaginary space during the brother's games. It is primarily used as an imaginary space in the play, but it is important to remember that it is also an extended-virtual space -- that the park truly exists in the world of the characters, not only in their imaginations. We must remember that the extended-virtual park is a restricted area to the "coloureds." This connection will be detailed later.

Imaginary Space

Finally, the very vivid imaginary spaces include: 
* the Chevy by the side of the road

* the trip through the town into the open country "into a flock of butterflies"

* the park of the brother's "game", where Morrie is white

* the two-man farm Morrie hopes to purchase some day

There are two kinds of space listed above which seem to suggest hope: an imaginary space drawn from memories of the past and one growing out of expectations for the future. The Chevy establishes a spatial image of Morris and Zach's happy youth, when a boy's color did not seem to be an issue. They engage in an imagination game involving the spatial memories of a rusted Chevy at the side of the road which is clustered with images of the open country and a flock of butterflies. Morrie says, during this game, "This is rare, Zach! We've driven into a flock of butterflies. We've found it, Zach. We've found it! This is our youth!" (45) This childhood game in the Chevy allows them to travel freely, "to hell and gone" as Morrie would say in his enthusiasm for freedom (45). The Chevy represents the youthful hope for freedom.

In comparison, Morrie dreams of someday living on a farm where a man's color will no longer be an issue. "But when we go, zach, together, and we got a place to go, our farm in the future. . that will be different" (17). The farm can best be understood in terms of the images that cluster around it. In this cluster (farm, map, roads), the focus seems to be again on escape. All of these are images of hopeful escape for both brothers, but especially for Morris. Morris 
desperately looks toward purchasing the farm as a refuge from the cruel world, just as he originally took to the road to escape Korsten and his brother. The farm, the roads away from Korsten, and the map of Africa, all provide the promise of escape, and once again Morris states, "We are going to get to hell and gone out of here. . ." (17). Showing zach a map, Morris further expresses his enthusiasm for this hopeful dream of escape:

. . You want to know what it is? A map. . .of Africa. Now, this is the point, zach. Look there. - and there. . . and down here. . .Do you see? Blank. Large, blank spaces. Not a town, not a road, not even those thin little red lines. And, notice, they're green. That means grass. I reckon we should be able to get a few acres in one of these blank spaces for next to nothing, zach. (17)

The farm represents the adult hope for eventual escape.

One other space that should be described more fully is the imaginary space of the park used by Fugard in the climatic moment of the play. This park is described as being hilly, treed, filled with butterflies and benches, and relatively empty of people.

MORRIS. What's on the other side [of the gate]? ZACHARIAH. Does it matter?

MORRIS. It does if we're going to play this thing properly.

ZACHARIAH. Trees.

MORRIS. Ah. Tall trees, with picnics in the shade.

ZACHARIAH. Grass

MORRIS. Green, hey! We'll make it spring.

ZACHARIAH. Flowers with butterflies.

MORRIS. That's a good touch.

ZACHARIAH. And benches.

MORRIS. How thoughtful! I'll want to rest. (75)

This space is also an image of hope, for in the park of their 
imaginations freedom is not restricted. It is an image strongly connected to their youthful memories; notice the reference again to the green grass and to the butterflies, a clear point of comparison between the hopeful images of the Chevy and the hopeful images of the park. Unfortunately this image of hope is not one which can sustain itself, for the more the brothers "play" in the park, the more the reality of the extended-virtual spaces of the location and the park itself begin to invade. But, at this moment when the park is first referred to as an imaginary space, this space seems tranquil and safe, lying in sharp contrast to the impending violence which erupts at the end of the game.

When the brothers begin the game in the imaginary park at the climax of the play, they are playing in a space which is quite real to zach as his place of work and quite exciting to Morris as he has the potential to pass for white. This cluster (park, gate, hills) seems to center on the hope of possibility but eventually yields to the threat of a potential reality. Fugard, in his preface to the play, describes the game involving these spaces as "looking into the maws of hell" (6). There is danger here if the extended-virtual park is allowed to overcome the imaginary park of the brothers' hopes. This contrast is important to the play's meaning.

\section{Spatial Alignments}


Listed below are the dramatic alignments of space most strongly connected to the action of Blood Knot (they are listed in the same manner as Burke identifies -- what vs. what):

$$
\begin{aligned}
& \text { * shack vs. location } \\
& \text { * shack vs. farm } \\
& \text { * shack vs. park }
\end{aligned}
$$

These alignments are particularly important, especially when viewed in the context of the categories of spaces they entail. As mentioned in the previous section, Fugard's description of the virtual space of the shack - and the brothers' use of this room - is quite explicit. It is a tiny refuge -- small, but safe and secure. Morris keeps it thoroughly clean and organized, which is a direct contrast to the chaos of the extended-virtual location which lies outside the walls of the shack. The differences between these two spaces were evident already in the previous section.

The tiny shack must also be considered in contrast to the wide-open spaces of the park and the farm. These two imaginary places are created during Morris' and zach's games: the private two-man farm desired by Morris, and the park of zach's everyday reality recreated by the brothers' imaginations. During these games, the brothers essentially engage in a play within a play, resulting in a vivid comparison between the visible (to the audience) squalor of the shack and the hopeful images of the games. In these comparisons, it is not the shack which seems the desirable space. The farm and the park seem full of promise; vast 
spaces filled with possibility. The farm manages to maintain that promise through the course of the play. Unfortunately, the park becomes a place of unseen danger, perhaps more dangerous than any other space explored in the play.

\section{Meaning}

There seems to be a distinct difference between the youth of these two brothers and the present reality of their lives, differences which are boldly expressed by Fugard in his use of space. The spaces which arise from the memory of youth are the imagined spaces: the open country, the chevy amidst a flock of butterflies. Compare these spaces to the virtual and extended-virtual spaces connected to the present -- the shack, the rotten lake, the squalor of Korsten -- and it is obvious that the lives of the two brothers have become more complicated, much darker.

Why has this occurred? Zach seems to think that it is because Morris went "on the road. . . [and] came back quite white" (69). Morris is light-skinned, Zach is dark, yet they are brothers. Fugard, as he writes about the "quality of life in South Africa," has placed "two characters in a tight, passionate and tormented relationship which. . indirectly reflects the S. African situation" (Walder 1985, 54). Thus the reality of the brother's lives, the decay and the squalor of the spaces which surround them, is representative of South African reality. But Fugard is not satisfied with simply 
reflecting reality. He also intends to suggest possible outcomes.

The hopeful, positive possible outcome of a light-skinned brother and a dark-skinned brother living together is reflected in the images surrounding the farm. "An illusionary dream of the future two-man farm is held out by Morris as a way of escaping their squalid shack in Korsten. (Walder 1985, 58). The spatial image of a private farm lying in the middle of a "blank space" on a map, far from rotten lakes and ugly towns, represents hope even if it is only an imaginary space. This would be the ideal.

Another possible outcome is also represented in an imaginary space, and, more specifically, in the use of this space. During the imagined trip through the park -- with Morris playing the role of a white baas and zach playing himself -- we receive a glimpse of what could happen if Morris exercised this choice and embraced his white skin.

The game begins hopefully, in a park which accords with all the imaginary spaces in the play. But eventually the reality of the extended-virtual park in which zach works invades the game. Eventually Morris begins to use the space as the white man he seems instead of the "coloured" man he is. Morris begins to speak of his longing to leave the location and his dark-skinned brother. "I'm too far away to see your eyes. In fact I'm almost free" (78). But his freedom has left zach behind. Morrie's reveling in his lighter skin and 
the potential of freedom it provides him is sharply contrasted to zach's frustration with his dark skin. In one brief moment in the park, we see what could result. Fugard describes the moment simply: "Zachariah stands above Morris on the point of violence" (84). Simply stated, but filled with meaning. In the study of proxemics there is a use of space called an angle of inclination. This use of space recognizes that the person who is in a higher position is in a superior, more powerful position. Thus, to place zachariah above Morris is to suggest a reversal of a societal norm in South Africa, and to do so at the point of violence is to suggest a frightening possible future indeed. The park becomes a place of violence.

It is important to note that the only space which is seen throughout the play is the one-room, tidy, tight shack. Why would Fugard place all this action and all these references to various other spaces into the setting of one small room? Why limit himself to such a restrictive space? Fugard has aligned a small, tight space against a large, open space. A major part of the South African society is encompassed in one small room -- a shack, this time, rather than the train compartment of Fugard's notebooks. Fugard is making a suggestion about the society South Africa has created. It would seem to be a suggestion that the brothers, light-skinned and dark-skinned, will need to learn to live together in the space that they create, even if that space is small and tight. The virtual and extended-virtual spaces and the harsh reality they 
represent must be made to coincide peacefully with the imaginary spaces' communication of hope. If the virtual or extended-virtual is allowed to dominate the imaginary, however, tragedy will result. Reality can destroy hope. When Zach asks Morris if they could live any other way, Morris answers, "No. You see we're tied together, Zach. It's what they call the blood knot. . .the bond between brothers" (85). South Africa, also can live no other way. Light-skinned and dark-skinned people remain and must live together in the world they have created. They must hope for the future and work toward escaping to the future. It is their blood-knot. 


\section{PEOPLE ARE LIVING THERE}

The three main characters in this penetrating psychological study of frustration and loneliness spend an evening together in the kitchen of the cheap Johannesburg house where they live. (Fugard $1970,3)$

The Cape Times wrote of Fugard's 1970 play People are Living There, "[It] confirms Fugard's position as perhaps the most important writer in the country today and ensures for him a place of honour in the history of South African theatre" $(1970,3)$. While few people today would proclaim this play one of Fugard's best, it continues to deserve recognition. It is an interesting play, which, like Blood Knot, takes place entirely within the limits of one room -- the kitchen of the boarding house owned by the protagonist of the play, Milly. The other three characters (Don, Shorty, and Sissy) are all renters in the house. The action of the play finds Milly, after having been rejected by her lover, desperate to prove that she is vital, alive, and still able to enjoy life. She coerces Don and Shorty to help her celebrate her fiftieth birthday, and to help her show the German lodger who jilted her that she can have fun on a Saturday night without him. The celebration which is staged in the dingy kitchen is the crux of the play. 


\section{Identification and Classification}

\section{Virtual Space}

There is only one virtual space in this play: the kitchen. This must be explained fully before any investigation into meaning can occur. First, it is necessary to understand Fugard's vision of the actual set. He describes it in the following stage directions:

The kitchen of an old, double-storeyed house in Braamfontein, Johannesburg. Two doors--one leading to the backyard and an outside room where Don lives, the other to a passageway and so to the rest of the house. There is also a window looking out onto a street. Center stage is a kitchen table and chairs with an electric light hanging above them. For the rest we see, but not too clearly because the light is bad, the walls, a kitchen dresser, shelves and in one corner an old-fashioned gas stove. (5)

This actual set results in the virtual space supplied by Fugard to his characters. The kitchen is a part of the boarding house owned by Milly, and it is the site of all the action of the play. At times through the play the kitchen seems a pleasant place for Milly ("I'm pleased to be here with you", 51), but at other times it seems quite unpleasant. In fact, in all ways but one, this is a constantly ambivalent space for Milly. The one exception is articulated in a recurring phrase, when Milly reminds us that, if nothing else, the place is hers: "This happens to be my house! Let's get that straight" (71). This sense of territoriality Milly has 
for the place has meaning. It is a safe haven for her, a private place, a place where she is in complete control. The kitchen in this boarding house is a space where people gather at the invitation of the cook. Milly's kitchen therefore becomes a space where she has some control over its use and its potential for being full of life and activity.

This concept is supported by the images of the party which cluster around the kitchen. In this cluster, the focus seems to be on the potential of life and activity in the kitchen. Milly calls for a party in the kitchen, so that she, Don, and Shorty can also have a good time. She declares the kitchen is "not a boxing ring" (12) and that the celebration should be loud enough that everyone will know the people inside the kitchen are "carefree" (45). The kitchen is Milly's haven, and she insists that its potential for life be fulfilled.

Notice, as in Blood Knot, there is, in additon to two doors, a window described in the stage directions for the set. Once again, other than the dictum that the window looks out onto a street, Fugard is not specific about the view through the window (5). It is probable that the window is present to provide a visual reminder of the tension which exists in this play between the virtual space and the extended-virtual. This tension will be explored later. 
Extended Virtual Space

There are several specific references to spaces which extend beyond the kitchen. Extended-virtual spaces are listed and described below:

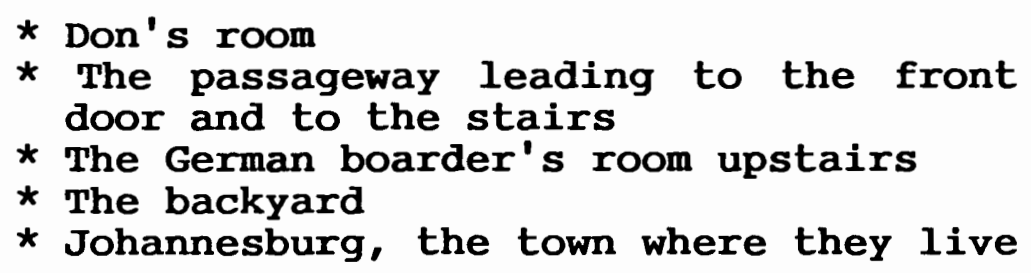

The area outside the kitchen--anywhere outside the kitchen--seems to have great meaning for Milly. Milly refers to all of it quite often. But, like the kitchen, the extended spaces are ambivalent. Whether it is the house beyond the kitchen, the backyard, or Johannesburg, it is both frightening and desirable.

To define the house beyond the kitchen, Fugard clusters around it a series of images which seem to represent rather intense emptiness to Milly. Toward the middle of the play, she makes the following observation to Don:

MILLY. Well, I walk into a room -- I'm by myself because he's [the German boarder] at work and you're somewhere else and it's all quiet so I'm alone -- then $I$ walk into $a$ room and $I$ stand still and think about something to do. I look around, you see, for a little task to while away the time. and then it comes. I begin to notice. It's like a plug has been pulled out and something's drained away down a big, black hole, leaving everything stranded. Th i $\mathrm{ng}$ s stand too still. Chairs and tables. A 11 empty and still. . . and stupid. That's

the word! stupid. Like that chair. I know what it is. I look at it and I say 
Chair. But it doesn't help. It goes on being empty and useless. Once it got so bad I said: Well I'll prove it. So I sat down. But that made it even worse. (34)

The house seems empty to Milly, empty of life, empty of meaning. None of the things with which she has filled her space seem to have a purpose. What use are chairs and tables if no one ever visits to admire them and make use of them? If the space does not provide Milly with the satisfaction of something to do, what use is that space? It is not useful; it is empty. At times, the emptiness seems to be so intense that it causes Milly to explore another image to explain her feelings -- the spatial image of a grave.

MILLY. - . .I must have dropped off then, because the next thing $I$ knew it was cold and dark and .. I don't know. Empty! Waking up is a cold business in an empty house. Specially old houses. Wherever you look it's just walls. God, it's depressing! Put out the light and you're as good as in your grave. (9)

This emptiness seems so much more intense when it is compared to another cluster of images, also of the extendedvirtual space, those of the streets and the city. Near the end of the play she cries, "But there's a street outside there, Don! All the people! Rush hour traffic. Right outside that front door!" (73) Milly seems to feel that real life is happening outside that front door on the streets of the town. But it is also a world which frightens her, which feels foreign. When Don asks Milly if she has opened the door to the house today, she says "suddenly conscious of herself and her predicament. ' $I$ 'm still in my nightie. I haven't got 
dressed . . yet'" (73). She is scared of what lies beyond the kitchen, for it means risking her safety, risking her comfort. The extended-virtual city space is too large, too open for comfort. It appeals to her, and it scares her at the same time.

Fugard reinforces this sense of the city by depicting a struggle between Shorty and his wife.

SISSY. Let's go away from here [Milly's house]. SHORTY. Aren' $t$ we happy here?

SISSY. I'm not. They don't like me. You don't protect me you know. You let them scandal about me.

SHORTY. Where do you want to go?

SISSY. How must I know? Somewhere nice.

SHORTY. Shamley Boarding House.

SISSY. Back there! Are you mad? Cape Town.

SHORTY. Cape Town? Cape Town.

SISSY. You asked me, so I'm telling you.

SHORTY. But what about my job?

SISSY. Ask them to transfer you.

SHORTY. I know nothing about transfers, Sissy.

SISSY. Well ask them. Ask George.

SHORTY. But I don't know the streets down there, Siss! I'll never get the letters right. Please, not Cape Town.

SISSY. So must it be Braamfontein all my life? (68)

Sissy and Shorty, like Milly, are drawn to the extendedvirtual space of the city, but shorty feels frightened. He feels as Milly feels -- he wants to go to Cape Town, but it scares him. So Cape Town seems to be the ideal for most of the characters in the play. But the space associated with the city is also frightening, and the characters can not seem to risk entering them. Once again, the images used to define the extended-virtual spaces are ambivalent. 


\section{Imaginary Space}

There are two imaginary spaces established in the play: one defined by Milly, and one by the cynical Don.

* the street where Milly lived as a girl
* Don's "rooms" of the future

At one point in the play, Milly discusses her memories of a street in her past captured in her imagination:

MILLY. - . They all seemed happy with it back in old Pringle street. So I believed them. I was young. And. . I was young! Yes. Come to think of it. Me. Once. - Pringle street. Number nineteen, near the top. (62)

Again, real life--a life worth living--possibly lies outside the kitchen on another street; this time a street in her memory. It was a hopeful space, invoked from the past. At least in her memory, it seems to be a space she could have handled, used and enjoyed. In her memory of her youthful enthusiasm, she feels that she could have risked entering Pringle street, thereby enjoying its life.

But one character, the cynical boarder Don, believes that nothing would really change even if Milly would risk leaving her haven. Life, he believes, has nothing to do with being inside a haven or outside in the streets. Rather than the world of the present, or the streets of the past, Don refers to the imaginary rooms of the future. An imaginary space is invoked which is not hopeful. Don speaks of a time when all people are eventually forgotten:

DON. - But even if you are one of the lucky 
ones, sooner or later you end up in the cold again. Nothing is forever. They die, or you get divorced. One way or another they go, they forget, and you end up in your little room with your old age pension and a blind bitch for friendship. From then on it's just a matter of days. - . One day, one more sunny day with the pigeons flocking and the people passing, you're not there. But who misses you? Who's to know that inside a room, finally, forgotten by the world. . . (37)

Don is of the belief that all spaces are essentially devoid of hope. He feels that the eventuality of living and dying in an empty room, forgotten by the world outside, is inevitable. Although Milly is frightened of the world, she does not have the same resignation about her chances of reaching the freedom of the public space of the outside.

These three spaces--the virtual kitchen, the extendedvirtual outside world, and the imaginary streets of the past and the empty rooms of the future--begin to indicate the play's meaning.

\section{Spatial Alignments}

The dramatic alignments of space most directly connected to the action of People are Living There pit virtual space against extended-virtual or imaginary space. These alignment are:

$$
\begin{aligned}
& \text { * kitchen vs. outside city } \\
& \text { * Pringle street vs. house }
\end{aligned}
$$

The alignment of the kitchen versus the outside city is, as has been mentioned before, the most evident and most 
repeated pattern in the play. Consider the following quotes:

DON. The air outside is not as fresh as you think.

MILLY. Better than the lot in here thank you very much. (8)

MILLY. Yes Milly! Go out there and stop one of those cars and say Milly wants to know where is it? Where do you get this good time every Saturday night? She's stuck in her kitchen with two good-for-nothing nitwits, so can she come? (27)

In both of these quotes the virtual spatial image of the kitchen is pitted against the city. It is a strange paradox that the haven of the kitchen can also seem a trap. This paradox results from her ambivalent feelings about the outside--she knows "life" exists outside the kitchen, but she is afraid to risk leaving her haven. At one point in the action of the play, the contrast between the outside of the kitchen and the emptiness within becomes too much for Milly. She decides that she also is going to have a good time, but of course she can only risk having a good time in the safety of her kitchen:

MILLY. Because guess what's going full swing when they walk in through that front door? A party!

SHORTY. That don't sound so bad Milly.

MILLY. What do you say, Don?

DON. You've forgotten one thing. The party. where does that come from?

MILLY. Us?

DON. You mean you, him and me. .

MILLY. - . are going to have a party! Let me give you the picture this time. Half a bottle of Muscadel at the bottom of my wardrobe gets the ball rolling. We buy a cake, hang up some decorations. I've got all that stuff left over from Christmas. Let's be care free man! Laughing and singing until 
the cows come home. And them upstairs having to endure it all the time. (45)

\section{Meaning}

Dennis walder states that during the time of writing People Are Living There Fugard was fascinated by the writings of Camus -- especially by Camus' reflections on a city. Walder quotes the following words of Camus: "Can one be moved by a city where nothing attracts the mind, where the very ugliness is anonymous, where the past is reduced to nothing?" (1985, 53). Fugard's answer to this is yes. One can be moved by such a city. Fugard's use of the extended-virtual city in this play seems to suggest this answer to Camus' question. The city has created anonymity, has reduced the past to nothing--especially Milly's past; Milly feels forgotten in this city, and yet she is moved by its potential. Because she cannot find the life she seeks in her haven, she believes that life must exist out in the noisy streets of the city. She wants to discover what it has to offer. She believes that there must be the active life she has not enjoyed. If only she could leave her kitchen, she would be fulfilled. But she cannot leave. She is too fearful of giving up her haven. The result of this inability to leave will be, as Don says, "One way or another [people] go, they forget. . . But who misses you? Who's to know that inside a room, finally, forgotten by the world. . " (37). Even the potential of dying forgotten 
does not propel Milly outside the kitchen.

So Milly remains in her house. It is this house which becomes the overwhelming spatial image in the play. When discussing the development of symbols, Burke uses an example which may explain the role of the house, and its meaning. Burke said, "A house lived in by a woman. . would be 'representative' of the woman who was 'identified' with it" (1967, 29). If this is true, if the house represents Milly, consider again the implications of the following statement made by Milly:

Well, I walk into a room -- I'm by myself because he's at work and you're somewhere else and it's all quiet so $I$ 'm alone -- then $I$ walk into a room and $I$ stand still and think about something to do. . . . It's like a plug has been pulled out and something drained away down a big, black hole, leaving everything stranded. Things stand too still. Chairs and tables. All empty and still. . . and stupid. That's the word! stupid. Like that chair. . It goes on being empty and useless. (34)

"Empty and useless" is the description of the house and the things within the house. That may also be how Milly has begun to view herself. No wonder, then, that she rebels against this image. No wonder then that she takes idealized trips to her past, to Pringle street. No wonder she has established a boarding house and gathers her boarders around the table in order to help her celebrate her birthday. She simply wants to make her house noisy, exuberant, so that people will "stop in the street . . [and] say: People are living there." She is desperately trying to make sure people know that she is still living. As she said: "Mildred Jenkins, you are still alive!" 
(64). So she tries to take her virtual space -- the kitchen-and fill it with so much that it will spill into the extendedvirtual house and city full of energy. If she can't brave leaving her haven, then she will make her haven into what she desires. She decorates the kitchen and tries to fill the room with a noisy party, hopeful that she can recreate in her kitchen what she thinks exists outside in the city streets -life.

Fugard does not seem driven to determine whether Milly's actions are commendable or deplorable. He rather seems to suggest it may simply be an inevitable reaction by a person as lonely, isolated and afraid as Milly Jenkins.

Does this communicate meaning to the larger society of South Africa as did Blood Knot? Perhaps not as universally, for not all people find life to be empty or are ambivalent in their feelings. But Fugard does seem to suggest here, and in other plays such as A Lesson from Aloes, that apartheid has affected all people in South Africa. Even if white, as Mildred, one is affected by the repressions the society has inflicted. Apartheid results in legal and physical repressions of the freedom of the non-whites, but it also results in the societal and spiritual repression of many of the whites who live and abide by such a decision. It is not just the blacks who are hurt by the legacy of apartheid. Rather large segments of South African society are also hurt by this legacy. 
THE ROAD TO MECCA

A city, Marius! A city of light and color more splendid than anything I had ever imagined. There were palaces and beautiful buildings everywhere, with dazzling white walls and glittering minarets. strange statues filled the courtyards. The streets were crowded with camels and turbaned men speaking a language $I$ didn't understand, but that didn't matter because I knew, oh I just knew, it was Mecca! And I was on my way to the grand temple. (Fugard 1985, 54)

William A. Henry III wrote of The Road to Mecca, "Fugard's wisest, most balanced and most nearly universal play" $(1987,70)$. First produced at Yale Repertory Theatre in 1984 and published in 1985, this play has quickly become, along with MASTER HAROLD... and the boys, Fugard's most familiar and most renowned work. Part of this play's appeal stems, as Mr. Henry notes, from its universality. This is not to suggest that the play does not deal with South Africa and other such issues with which Fugard is identified. It simply means that the story told, the struggle of people young and old to find a place in this world, is universally experienced. And, in this story, space is an essential element.

The action is simple. The reclusive Miss Helen, an elderly widow living alone, has devoted herself to the creation of a "Mecca" within her own yard and house through the artistic construction of statues and mosaics. To her, 
this Mecca is something quite spiritual and quite safe. But to the people of her town, especially her pastor, Marius Byleveld, it is the creation of something not quite sane. Pastor Byleveld would like to encourage Miss Helen to enter a retirement home. Miss Helen, with the help of her outspoken young friend, Elsa Barlow, firmly asserts her own beliefs and takes control of her own life. In this assertion, the role of Miss Helen's home and the Mecca contained within is essential.

\section{Identification and Classification}

\section{Virtual Spaces}

There is one essential virtual space -- Helen's living room. Fugard is very explicit about his vision of the actual set -- in fact, he needs to be, if the "Mecca" of the end is to be created. He describes it at the very beginning of the script:

The living room and, leading off it, the bedroom alcove of a house in the small Karoo village of New Bethesda. An extraordinary room by virtue of the attempt to use as much light and color as is humanly possible. The walls -- mirrors on all of them -- are all of different colors, while on the ceiling and floor are solid, multicolored geometric patterns. Yet the final effect is not bizarre but rather one of light and extravagant fantasy. Just what the room is really about will be revealed later when its candles and lamps -- again, a multitude of them of every size, shape, and color - are lit. The late afternoon light does, however, give some hint of the magic to come. (3)

This setting is meant to create the illusion of a very 
uniquely creative home--a set which creates an extremely vivid virtual space. It is a space filled with light and color, creativity and imagination. It is a space which represents complete freedom, for it offers no limitations as to what can and cannot be done within its boundaries. In this regard, it may be helpful to read what Fugard writes of his memory of New Bethesda home in which the woman who was the play's inspiration actually lived.

In the course of looking at various houses and getting to know a few of the locals, reference was made to a rather strange character who lived in the village. Her name was Helen Martins and the people were kind of apologetic about her because they regarded her as a little crazy. They said that her craziness took the form of rather silly statues and sculpture that she made and had all around her house. I obviously couldn't resist the temptation of strolling in the direction of her house and seeing Miss Helen's "Mecca" for the first time.

- . Then her life suddenly erupted in this remarkable way in terms of her sculpture. suddenly there was the first statue in the garden, and then over the next fifteen or seventeen years she worked away, with obsessive dedication, at what must have been a personal vision. After her death $I$ went on to discover what she had done inside her house as well -- as remarkable a feat as what she had done outside with the sculptures. (1985, viii-ix)

It is additionally helpful to explore how Fugard has Elsa react to the house and its yard, "Elsa takes stock of the room. Not an idle examination; rather, she is trying to see it objectively, trying to understand something" (23). Elsa reacts to the house much as Fugard reacted to the original home, with curiosity and an open mind, seeming to enjoy its uniqueness while not quite understanding its message. Elsa "looked around the room and laughed with delight" (37). Elsa 
describes her first introduction to Helen and her home in the following words, followed by Miss Helen's description of Elsa's reaction to the interior of the home:

ELSA: Who would ever believe it? That you found yourself being asked to point out the direction of Mecca--not London, or New York, or Paris, but Mecca--in the middle of the Karoo by a little lady no bigger than a bird surrounded by camels and owls. . . and mermaids!. . .made of cement? Who in their right mind is going to believe that? And then this [The room], your little miracle of light and color. (35)

HELEN: - . . I was so nervous I didn't know what we were talking about anymore while I sat here trying to find enough courage to get a box of matches and light the candles. But eventually I did and you . . .you looked around the room and laughed with delight! You liked what you saw! This is the best of me, Elsa. This is what I really am. Forget everything else. Nothing, not even my name or my face, is me as much as those Wise Men and their camels traveling to the East, or the light and glitter in this room. The mermaids, the wise old owls, the gorgeous peacocks. - .all of them are me. . ( (37)

So Helen strongly identifies with her creation, and Elsa --and indeed, Fugard--react positively to it. Marius, on the other hand, reacts quite differently, with fear and disapproval of the space that Helen has created:

MARIUS: . . This is not exactly the sort of room the village ladies are used to or would feel comfortable in having afternoon tea. as for all of that out there. - .the less said about it, the better. (80)

MARIUS: - . A life [Helen's] I care about as deeply as any I have known, trapped now finally in the nightmare this house has become. - . I know I'm not welcome in here anymore. I can feel it the moment I walk in. It's unnatural, Helen. (95) 
Marius finds Helen's creation to be almost blasphemous for it seems close to idolatry. Thus, his discomfort comes not only out of concern for her physical welfare, but her spiritual well-being as well. Marius recognizes the creation knows no boundaries -- even the audience can see the creativity spilling out the window into the extended-virtual space of the yard. ${ }^{7}$ This alarms Marius, for he is a man whose sense of spirituality requires laws. Helen's beliefs require freedom.

\section{Imaginary Space}

Because there is such a close affinity between the play's virtual space and the play's major imaginary space, the latter will be discussed before discussion of the play's extendedvirtual spaces. The imaginary space, "Mecca," is the evolution of Helen's creations into something more magical than the virtual initially represents. With the addition of candlelight and imagination, the artworks of the yard and living room become an entire world unto themselves. It may be helpful to show the dynamic use of the set which results in the creation of Helen's imaginary "Mecca." The level of territoriality and identity Helen has invested in the room becomes quickly obvious to the audience. What follows are sections of a speech with which the play climaxes; the moment

7 This is the one occasion among the plays discussed in this thesis when Fugard is explicit about the ability of the audience to see the yard through the window of the set. 
at which Helen reveals the room in all its splendor and all its meaning. In order to facilitate full understanding, the entire account of the creation of "Mecca" will be reserved until later in the study.

HELEN: -. . Light them all, Elsa, so that I can show Marius what I've learned.

Elsa moves around the room lighting all the candles, and as she does so its full magic and splendor is revealed. Miss Helen laughs ecstatically.

- . When I lie in bed and look in that mirror I can see that mirror, and in that one the full moon when it rises of the Sneeuberg behind my back! This is my world and $I$ have banished darkness from it. . (96)

This is Helen's space. She has created it and she can control its transformation from virtual to imaginary. This space embodies all that Helen hopes for and believes in -- freedom, creativity, and the expression of self. ". . Nothing is as much me as those wise Men and their camels traveling to the East, or the light and glitter in this room. . The only reason I've got for being alive is my Mecca" (37). Helen's Mecca is her entire life.

\section{Extended-Virtual Space}

The extended-virtual spaces, as they clash so vividly with the other spaces, strongly suggest the undesirability of the outside world. These spaces include: 
* the Great Karoo

* the village, New Bethesda

* the retirement home

The Great Karoo is a desolate area of South Africa located in the southern region and is so named after the Hottentot word meaning barren. Again, it is important not only to understand the extended-virtual space of the Karoo, but to see it through the eyes of all three characters, for all have different reactions to it. Below are listed three references to aid in this process:

ELSA: - .TO me it has always been a landscape of extremes, too hot or too cold, too dry or else Miss Helen is writing to me about floods that have cut off the village from the outside world. It reminds me of something I once read where the desert was described as "God without mankind." (63)

MARIUS: You judge it too harshly, Miss Barlow. It has got its gentle moment and moods as well. - all the more precious because there are so few of them. We can't afford to take them for granted. As you can see, it feeds us. Can any man or woman ask for more than that from the little bit of earth he lives on? (64)

HELEN: It's really not as bad as you make it sound. The few times I've been away, I've always ended up missing it and longing to be back. (14)

In this space, it is Marius who is fully comfortable, while Helen is only mildly positive and Elsa is openly negative. It seems to be an open space without edges, without any territoriality or sense of ownership -- a space which treats its visitors harshly and offers no haven. The Karoo also seems to necessitate the equally harsh and repressive nature 
of the village's form of religion, a religion full of laws to help the residents adjust to the barren empty but threatening Karoo. As Elsie says in reference to the desert, "It's so obvious where you Afrikaaners get your ideas of God from" (13).

The village of New Bethesda is also an important extended-virtual space. It seems to be a very provincial town, quite isolated and almost regressive. Elsa, when describing this "godforesaken" (34) village, says:

Well, it can't cut itself off from the twentieth century forever. Honestly, coming here is like stepping into the middle of a Chekhor play. While the rest of the world is hoping the bomb won't drop today, you people are arguing about who owns the cherry orchard. Your little world is not as safe as you would like to believe, Helen. (21)

The village is a dangerous place and oppressive, but in a different way than the Karoo. It is dangerous because it has too many edges rather than too few. It is too restrictive and it is too private. The town and its spiritual leader, Marius, follow rigid rules of what is right and what is wrong, what is proper and what is sinful. This town offers little forgiveness to those who trespass beyond the boundaries established by these rules. Helen has trespassed, and Elsa warns her of the danger which could result in the quote above. There is one other important extended-virtual space identified in the play: the retirement home. This retirement home is where Marius would like to move Helen, both because he is beginning to doubt her ability to care for herself and 
because he is afraid for her as she lives in her "nightmare" of a home. He describes a few of the retirement home's virtues to Helen in the following passage:

Don't get worried, though. There's plenty of space for personal possessions and a few of your . . ornaments. . . (76)

This retirement home seems to be where Marius feels Helen will be most safe, both physically and spiritually. Elsa and Helen, however, feel far different. To them, the image of anything outside Helen's home is dangerous and frightening. This retirement home, like the village, seems too restrictive and too closed. It, like the village, would not allow Helen the freedom to be creative. Helen believes she is most secure at her home and her commitment to this home drives the play's action.

\section{Spatial Alignments}

Listed below are the image clusters and the dramatic alignments of space created by Fugard in The Road to Mecca. The clusters have been organized according to the most dramatic of the alignments which embody the action of the play.

Image

Clusters

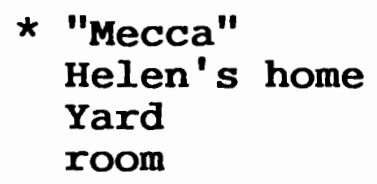

* Great Karoo

Cape Town

Retirement home 
Dramatic Alignment
* Helen's house vs. town

* "Mecca" vs. Karoo

* "Mecca" vs. town

* Own home vs. retirement home

It should be quite obvious that these patterns can be easily summarized in the following single dramatic alignment: this play seems to pit the world which Helen has created for herself, her imaginary and virtual "Mecca", her home, against the unforgiving territories of the rest of the relevant extended-virtual world--especially the Karoo, New Bethesda, and the retirement home. Elsa seems to highlight this conflict, in the following words:

. . I wish that I could make you realize what it's like to be walking down a dusty, deserted little street in a Godforsaken village in the middle of the Karoo, bored to death by the heat and flies and silence, and then to be stopped in your tracks -and I mean stopped! -- by all of that out there. And then, having barely recovered from that, to come inside and find this! Believe me, Helen, when I saw your "Mecca" for the first time, I just stood there and gasped. (34)

Elsa seems to have recognized from the very moment she saw the space that Helen had created how very different it was from either the Great Karoo or New Bethesda. She recognizes its importance, but she may not fully comprehend the meaning such spaces hold for the people who live within them. Again, she compares, in confusion, life on the Karoo with Helen's Mecca - and asks for help in understanding the meaning of the contrast:

I think I've had it. It's too much for one day. That woman on the road and now you. I honestly don't know how to handle it. In fact, at this moment, I don't think I know anything. I don't 
know what it means to be walking eighty miles to Cradock with your baby on your back. I don't know whether your Mecca is finished or not. And all I know about Darkness is that that is when you put on the lights. Jesus! I wouldn't mind somebody coming along and telling me what it does mean. (56)

Elsa may not understand what this all means, what the spaces signify and why they are so important, but Fugard provides us with every tool necessary to discover the meaning.

\section{Meaning}

One simple dramatic alignment suggests one simple meaning. Her home and her Mecca seem to suggest all that is good to Helen, all that is hopeful; while the town, the Karoo and the retirement home suggests all that is to be feared. Or, to phrase it another way: In Helen's Mecca resides her god, her spirituality, her peace and in the Karoo there is simply darkness, desolation, and an unapproachable God.

Elsa describes the Karoo as empty, silent, and the source of the townspeople's idea of God (13). Helen speaks of the Darkness that used to fill her room when she was a child in this town (55). Both images seem filled with fear and danger. Yet in both cases, it is Helen's Mecca which seems to be the refuge filled with hope. This Mecca is created out of the virtual space of Helen's home. Read the entire story of Helen's discovery of Mecca.

HELEN: I've told no one, not even Elsa, because it was a secret, you see, a very special 
one, and it had to stay that way while I was working on my Mecca. But so much has happened here tonight, it feels right to do so now. You brought me home from the cemetery, remember, and when we had got inside the house and you had helped me off with my coat, you put on the kettle for a pot of tea and then. ever so thoughtfully. . . pulled the curtains and closed the shutters. . You lit one [candle] for me before you left -- there was a lot of darkness in this room -- and after you had gone I sat here with it. Such a sad little light, with its little tears of wax running down the side! I had none. Neither for stefanus or for myself. You see, nothing hurt anymore. That little candle did all the crying in here that night, and it burned down very low while doing that. I don't know how much time had passed, but I was just sitting here staring into its flame. I had surrendered myself to what was going to happen when it went out. . . but then instead of doing the same, allowing the darkness to defeat it, that small, uncertain little light seemed to find its courage again. It started to get brighter and brighter. I didn't know whether I was awake any longer or dreaming because a strange feeling came over me... that it was leading me. - . leading me far away to a place I had never been to before. (She looks around the room and speaks with authority.) Light the candles, Elsa. That one first.

She indicates a candelabra that has been set up very prominently on a little table. Elsa lights it.

And you know why, Marius? That is the East. Go out there into the yard and you'll see that all my wise Men and their camels are traveling in that direction. Follow that candle on and one day you'll come to Mecca. Oh yes, Marius, it's true! I've done it. That is where I went that night and it was the candle you lit that led me there. . .

Elsa moves around the room lighting all the candles, and as she does so its full magic and splendor is revealed. Miss Helen laughs 
ecstatically.

. . . Light just one little candle in here, let in the light from just one little star, and the dancing starts. I've even taught it how to skip around corners. Yes, I have! When I lie in bed and look in that mirror I can see that mirror, and in that one the full moon when it rises over the Sneeuberg behind my back! This is my world and I have banished darkness from it. (96)

The little candle Marius lit led Helen to a new "place" --a place she calls "Mecca," which is neither defined by the Afrikaaner Christian view, nor by the harshness of the Karoo. This world is safe to Helen. In this space she has created, she feels spiritually and physically whole. It is quite interesting to note that Marius does not understand this phenomenon at all. He does not understand its meaning. He is happy with the town. He finds peace in the Karoo: "It has got its gentle moments and moods. . . it feeds us" (64). His sense of faith leads him to be comfortable in such stark surroundings filled with such stark contrasts and such harsh realities. This seems, to Marius, to be an accurate reflection of the world God has created. So when he is faced with the realization that his world and his faith is not Helen's, he is disappointed and confused.

Mecca! So that's where you went. I'11 look for it on my atlas of the world when I get home tonight. That's a long way away, Helen! I didn't realize you had traveled that far from me. So to find you I must light a candle and follow it to the East! No. I think I'm too old now for that journey. . . and I have a feeling that you will never come back. (100) 
If Mecca is not for Marius, he is not alone. Elsa recognizes that this Mecca is not for everybody: "There's no Mecca waiting for [the homeless woman] at the end of that road, Helen" (105). Helen also recognizes that fact. She knows that the road to her Mecca was one she alone had to travel, but she seems to suggest that there may be a type of "Mecca" for everyone (108). Perhaps it is simply a fact that Fugard believes -- that a person must discover his or her own source of peace and light; his or her own Mecca within which one might take refuge against the world. And, perhaps particularly in South Africa, this discovery of a personal Mecca and the acceptance of the Meccas of others is essential to spiritual health. 
CHAPTER V

My Children, My Africa

I've always thought about the location as just a sort of embarrassing backyard to our neat and proper little white world, where our maids and our gardeners and our delivery boys went at the end of the day. But it's not. It's a whole world of its own with its own life that has nothing to do with us. (Fugard 1990, 20)

When the character of Isabel speaks these words to the audience, she is articulating one of the central images (the location) in the play My Children, My Africa. This is one of Fugard's most recent plays, first performed in 1989 (published in 1990), and it is his most didactic. Spatial references, essential to the theme of the play, are used by Fugard as a tool of instruction. Fugard hopes to help his audience understand the world of the location and comprehend how changes in South African society, both on the location and in the white towns, will best be achieved.

Mr. M is a powerful, dedicated black teacher in the location who strongly believes in the power of education and words to facilitate change. His prized student, Thami, is beginning to doubt that power. He has begun to explore the 
possibilities of more radical movements toward change. He has begun to abandon all that he has learned. Thami's choices strongly affect both Mr. $M$ and his new white friend, Isabel. The question around which the play revolves is: How do we best cause change in the world of a repressive society? Where does the best hope lie?

\section{Identification and Classification}

\section{Virtual Space}

The only major virtual space is the classroom of zolile High School. Nearly the entire play takes place in this classroom of the location high school. But in this play, contrary to his previous works, Fugard does not describe in detail the appearance of the set in his stage directions. In fact, notes for the original production, including those in the published text, suggest a very presentational design -simply the hint of a classroom is suggested through selective realism. This is very different from Fugard's past plays explored in this study, so it is very possible that this simple fact offers some special meaning. As the window in Miss Helen's house allowed the audience to see the potential for her Mecca to spill into the extended-virtual space, 
perhaps the lack of a definitive space will better allow the audience to "see" the role of education in the world outside the theatre.

What we do learn of the classroom comes from the dialogue of the play. In a sense what we "see" depends on something akin to what has been described in this thesis as imaginary space. The virtual classroom is a rather generalized classroom which has to be understood in terms of how the characters feel about it. Isabel describes the classroom, and the effect it had on her the first time she visited it, during a monologue which is delivered to the audience:

They were waiting for us in what they called Number One Classroom. Honestly, I would rate it as the most bleak, depressing, dingy classroom I have ever been in. Everything about it was grey -- the cement floor, the walls, the ceiling.

When I first saw it I thought to myself, how in God's name does anybody study or learn anything in here?. . .

- . When I stood up in front of those black matric pupils in Number One classroom, it was a very different story. I wasn't at home or in my dad's shop or in my school or any of the other safe places in my life.

I was in Brakwater! It was their school. It was their world. I was the outsider and $I$ was being asked to prove myself. .

- . You see, I finally worked out what happened to me in the classroom. I discovered a new world! (20)

Thami has a different view of the classroom. He is no longer excited about the place:

That little world of the classroom where I used to be happy, where they used to pat me on the head and say: Little Thami, You'll go far!. . That little room of wonderful promises, where I used to feel so safe, has become a place I don't trust anymore. Now I sit at my desk like an animal that has smelt 
danger, heard something moving in the bushes and knows it must be very, very careful. (51)

This classroom at zolile High school in the location is not only the setting, and actual set, of the play -- but it is a virtual space that holds much meaning for all three characters in the play. It is a space which is at once restrictive (due to its placement in the location) and open (due to the influence of education).

\section{Extended-Virtual Space}

There are two major spaces which fall into this category:

* the location, Brakwater

* the town

The location is the primary extended-virtual space. Again, we start with Isabel's description of it:

It's on the edge of town, on the right hand side when you drive out to join the National Road going north to Middleberg. Unfortunately, as most of Camdeboo would say, you can't miss it. I discovered the other day that it has actually got a name. . . Brakwater. . . from the old farm that used to be there. Now everybody just calls it "the location." There's been a lot of talk lately about moving it to where it can't be seen. Our mayor, Mr. Pienaar, he has got a point, you know. Our town is very pretty. - . The location is quite an eyesore by comparison. Most of the houses, if you can call them that! -- are made of bits of corrugated iron or anything else they could find to make four walls and a roof. There are no gardens or anything like that. You've got to drive in first gear all the time because of the potholes and stones, and when the wind is blowing and all the dust and rubbish flying around. . .! I think you'd be inclined to agree with our mayor. (20)

This location is a dirty, depressing place -- filled with 
shacks rather than houses and no greenery to lighten the atmosphere. This location, with its poverty and its squalor, is the home of both Mr. M and Thami, and is the source of their disagreement. It is symptomatic of the reason change needs to occur. The location is a place filled with danger and fear. Mr. M describes the streets of the location as "battlegrounds" (32), and once the boycott of the students begins he worries about his "children" being killed (67).

This danger is only increased with the anger that rises when the location and its decay is compared with the wealth of the town where Isabel lives. Isabel proudly feels the town is pretty (20), but Thami describes that beauty with rage (51). The location is also a space with severe edges -- edges which limit the freedom to the "coloureds" who live in the location and who may not travel at will to the town. This contrast with the town only increases the danger of and oppressiveness of the location.

There is one other extended-virtual space which is referred to by Mr. M when he brilliantly invokes the image of all of Africa. This is the space of the entire continent which lies to the north of the location. This is an extended reality which is known only when Mr. M journeys into an imaginary space. The words of Mr. M may help to make this clear:

. . . I went to the teacher who was with us and asked him: "Teacher, where will I come to if I start walking that way" - . . and I pointed. He laughed. "Little man," he said, "that way is 
north. If you were to start walking that way and just keep on walking, and your legs don't give in, you will see all of Africa! Yes, Africa, little man! You will see the great rivers of the continent: the Vaal, the Zambesi, the Limpop, the Congo and then the mighty Nile. You will see the mountains: the Drakensberg, Kilimanjaro, Kenya, and the Ruwenzori. . "Has teacher seen all that?" I asked. "No," he said. "Then how does teacher know it's there?" "Because it is all in the books and $I$ have read the books and if you work hard in school, little man, you can do the same without worrying about your legs giving in."

He was right, Thami. I have seen it. It is all there in the books just as he said it was and I have made it mine. I can stand on the banks of all those great rivers, look up at the majesty of all those mountains, whenever I want to. It is a journey I have made many times. Whenever my spirit was low and I sat alone in my room, I said to myself: Walk, Anela! Walk!. . . and I imagined myself at the foot of the Wapadsberg setting off for that horizon that called me that day forty years ago. It always worked! When I left that little room, I walked back into the world a proud man, because $I$ was an African and all the splendor was my birthright. (73)

This is an Africa filled with hope, for it is an open Africa, a free Africa. This splendor of Africa is also central to the meaning of the play, and is referred to several times -- even in the title of the play.

\section{Imaginary Space}

The imaginary spaces of this play have already been mentioned in the previous sections, for in almost every reference to space in this play, the reference contains characteristics of what has been termed "imaginary space" in this thesis. This "blending" of spaces has been accentuated by Fugard's choice of a rather presentational actual setting. 
The fact that imaginary space permeates every space in this play is in itself significant to the meaning of the play.

\section{Spatial Alignments}

Listed below are the dramatic alignments of space created by Fugard in My Children, My Africa.

$$
\begin{aligned}
& \text { * location vs. town } \\
& \text { * classroom vs. streets of location } \\
& \text { * "Africa" vs. location }
\end{aligned}
$$

Once again, these alignments have been chosen based upon a clear reflection of the action of the play. In this case, there are not many dramatic alignments, but the imagery of these alignments seems to dominate the entire script. Consider the alignment of location and the town, two extendedvirtual spaces, neither ideal. It is Isabel who seems to be most conscious of the differences between the two places. As was quoted earlier, Isabel has a very strong reaction to the appearance of the location in contrast to the appearance of her town. In another moment Isabel comments on how difficult it is to bridge the gap between the two spaces:

you know what I mean. Roll up and knock on your
doors like you were neighbors or just living down
the street. It's not as easy as that with us, is
it? You're in the location, I'm in the town. -
and all the rest of it. (28)

Isabel sees the difference, but it is possible that she does not feel the difference between the two spaces as does Thami. Consider his following comments: 
-. .I see a generation of tired, defeated men and women crawling back to their miserable little pondocks at the end of a day's work for the white baas or madam.

. Black people lived on this land for centuries before any white settler had landed! Does Oom Dawie think we are blind? That when we walk through the streets of the white town we do not see the big houses and the beautiful gardens with their swimming pools full of laughing people, and compare it with what we've got, what we have to call home? (51)

So the space of the location is pitted against the space of the town. Partially as a result of this tension, the dramatic alignment of the classroom and the streets is formed. This is a virtual space versus extended-virtual, which perhaps makes the alignment that much more powerful. Thami describes the classroom as something dangerous, a place that is not "safe" (51). He says that the classroom is "a political reality in my life. . .it's part of the whole political system we are up against and Mr. M has chosen to identify with it" (50). He is correct when he says that Mr. M identifies with the classroom, for it is in the classroom that Mr. M finds safety -- where education can lead to hope. "Come to school! Come to school! Before they kill you all, come to school!" (67). Mr. M truly believes that the classroom is the best place to learn about life -- and that the streets are dangerous. Consider the following description by Mr. M of his attempt to reach the school:

It was like being in a nightmare. I was trying to get to the school, I knew that if I didn't hurry I was going to be late so I had to get to the school. - .but every road I took was blocked by policemen and soldiers with their guns ready, or comrades 
building barricades. First I tried Jubulai street, then I turned into Kwaza Rd. And then Lamini st. . - and then I gave up and just wandered around aimlessly, helplessly, watching my world go mad and set itself on fire. . (66)

When there is danger, Mr. M seeks the haven of the school. Unfortunately, the school does not appear to the students to be a haven. There is finally a point at which it seems the students have decided to chose "another school. . .the streets. . " (51): Thami says, "There was a meeting in the location last night. . .we start boycotting classes tomorrow as part of that campaign" (60). This boycott, however, results in Mr. M's tragic death and Thami's becoming a fugitive. Isabel is left to make the decision to return to the classroom.

Finally, the space of Africa is pitted against the space of the location. There is the sense that the location does not facilitate access to the grandeur that is Africa--movement is quite obviously too restricted. Mr. M, for instance, must read of the land or imagine it in his mind in order to fully experience the pride that he rightfully feels for the land of his birth, Africa. The play suggests that, when physically restrained in South Africa's "locations," the people of the country can still "explore" Africa through their education. These dramatic alignments seem to clearly suggest meaning. 
John Kani, a native South African, when speaking in an interview with Theater Week magazine of his role as Mr. M in the premiere run of My Children, My Africa, said this of the play's meaning: "There was a time in the 80's when the slogan among the youth was 'Liberation Now; Education Later'. . eventually we learned that we have to carry the spear on one side and knowledge on the other" (Hurley 1990, 25).

My Children, My Africa is about education, and its role as an essential part of any revolutionary change. Anyone who would question this fact needs to read again the following dialogue between Thami and Mr. M:

THAMI. Yes. Yours were lessons in whispering. There are men now who are teaching us to shout. Those little tricks and jokes of yours in the classroom liberated nothing. The struggle doesn't need the big English words you taught me how to spell.

MR. M. Be careful, Thami. Be careful! Be careful! Don't scorn words. They are sacred! Magical! Yes, they are. Do you know that without words a man can't think? Yes, it's true. Take that thought back with you as a present from the despised Mr. M and share it with the Comrades. Tell them the difference between a man and an animal is that man thinks, and he thinks with words. Consider the mighty ox. Four powerful legs, massive shoulders, and a beautiful thick hide that gave our warriors shields to protect them when they went into battle. Think of his beautiful head, Thami, the long horns, the terrible bellow from his lungs when he charges a rival! But it has got no words and therefore it is stupid! And along comes that funny little, hairless animal that has got only two thin legs, no horns and a skin worth nothing and he tells that ox what to do. He is its master and he is that because he can speak! If the struggle needs weapons give it words, Thami. Stones and petrol bombs can't 
get inside those armored cars. Words can. They can do something even more devastating than that. . they can get inside the heads of those inside the armored cars. I speak to you like this because if $I$ have faith in anything, it is faith in the power of the word. Like my master, the great Confucius, I believe that, using only words, a man can right a wrong and judge and execute the wrongdoer. You are meant to use words like that. Talk to the others. Bring them back in the classroom. . (64)

My Children, My Africa is about education and the power it provides the people who want to initiate change. Mr. M says "Bring them back in the classroom." This classroom represents education. The entire play takes place against the background of a virtual classroom. It can even be argued that the audience is sitting in the classroom. The audience, too, is being taught. This "bleak, depressing, dingy classroom" is the powerful representation of the meaning of the play. Come to the classroom. Learn to use words. Learn to cause change. This is what Mr. M wants so desperately. This is the meaning of the space of the classroom.

"Come to school! Come to school! . . My lessons were meant to help you in this world. I wanted you to know how to read and write and talk in this world of living, stupid, cruel men. ." (68). This is Mr. M's cry when he realizes his students have left the classroom forever. This passage also explains the other principle space in the play -- that of the extended-virtual spaces outside the classroom. Thami thinks this world is a new school: "We have found another school. - the streets, the little rooms, the funeral parlors, the 
location. . " (74); yet, Mr. M recognizes it as filled with cruel, ignorant men. Note the end of the passage Mr. M speaks after his attempt to reach the school (cited earlier):

I ended up on the corner where Mrs. Makatini always sits selling vetkoek and prickly pears to people waiting for the bus. The only person there was little Sipho Fondini from Standard Six, writing on the wall: "Liberation First, then Education." He saw me and he called out: "Is the spelling right, Mr. M?" And he meant it! The young eyes in that smoke-stained little face were terribly serious.

Somewhere else a police van raced past me crowded with children who should have also been in their desks in school. Their hands waved desperately through the bar, their voices called out: "Teacher! Teacher! Help us! Tell our mothers. Tell our fathers." "No Anela," I said. "This is too much now. Just stand here and close your eyes and wait until you wake up and find your world the way it was." But that didn't happen. A police car came around the corner and suddenly there were children everywhere throwing stones, and tear gas bombs falling all around and $I$ knew that $I$ wasn't dreaming, that $I$ was coughing and choking, and hanging on to a lamp-post in the real world. No! No! (67)

The world outside the classroom is like a nightmare, filled with danger and deception. The students have embraced violence as the way to cause change and the police are imprisoning youths. The location has become angry and violent, the town has become scared and desperate, and all of South Africa has become a maelstrom of change. Yet, it is only in the classroom, Mr. M believes, that this change can take place in a way which acknowledges and glorifies the black population's African heritage.

In this play, the audience does not have the advantage of a representational set. The virtual classroom is somewhat 
undefined, allowing the imaginary image to fill the stage and spill into the entire world. Mr. M. believed in the power of education to strengthen the pride of the "coloured" people of South Africa, resulting in their freedom. Mr. M found his pride in the splendor of Africa which was his by right: ". .I walked back into that world a proud man, because I was an African and all the splendor was my birthright" (73). Thus, it was at Wapadsberg Pass, the sight of Mr. M's discovery of the power of Africa, and of the power of words, that Isabel most fully felt the spirit of Mr. M. At the end of the play Isabel visits this Pass and the imaginary space takes the stage--the hope becomes reality. Here she utters the words that Fugard seems to hope would speak for all of South Africa's children:

You gave me a little lecture once about wasted lives. . . how much of it you'd seen, how much you hated it, how much you didn't want that to happen to Thami and me. I sort of understood what you meant at the time. Now, I most certainly do. Your death has seen to that.

My promise to you is that I am going to try as hard as $I$ can, in every way that $I$ can, to see that it doesn't happen to me. I am going to try my best to make my life useful in the way yours was. I want you to be proud of me. After all, I am one of our children you know. You did welcome me to your family. The future is still ours, Mr. M. (84)

Isabel has come to discover what Fugard obviously believes: that change in South Africa must come, and will come, only when actively guided by education. Only then will change be effective and pervasive in South African society. 
The future lies in the classroom. 
CHAPTER VI

CONCLUSION

I don't think I will ever forget the extended conversation the three of us had in that compartment, watching South Africa slip past the window. All that is good and bad -- and worse than bad, rotten and wrong. . . in our second-class compartment broke loose from our hearts. (Fugard 1990a, 84)

This is the quote which opened this study. Fugard seemed to be very aware of space as a way to communicate tension and theme. Space to Athol Fugard is very real and communicates meaning. He sees South Africa -- its poor whites, its oppressed "coloureds", and its hopeful children -- in terms of spatial tensions. This is especially true of his plays. Whether he explores the frustration and pain of poor whites or "coloureds", he parallels the development of character with patterns of spatial images that dramatize the search for freedom in South Africa.

In fact, the three categories of space (virtual, extended-virtual and imaginary) apparent in Fugard's body of work are used in relatively the same fashion each play. All three have distinct meanings which is almost always carried over from one play to the next. In Fugard's plays, the actual settings and the virtual spaces created by them often seem to 
communicate safety. These spaces serve as a haven for the people who occupy them. The haven may seem magical and wonderful, as in Miss Helen's house, or it may be claustrophobic and stifling, as was Morrie's shack. It may be secure as Milly's kitchen or Mr. M's classroom. In every case, the virtual space provides a refuge for the characters - safety from the terrors and disintegration of the extendedvirtual spaces of Fugard's plays. Although he clearly loves the country, Fugard's South Africa is realistically portrayed as lonely, frightening, dehumanizing and dangerous. The locations of Blood Knot and My Children, My Africa, the city outside Milly's kitchen, the Karoo and village outside Miss Helen's Mecca -- all arouse some type of fear in the plays' protagonists. The extended-virtual spaces consistently reflect this. The final of the three types of space, imaginary space seems to communicate Fugard's ultimate message. His imaginary spaces are often of the South Africa that could exist, or did at one time when viewed through the eyes of a child. The dominant imaginary spaces are generally images of hope.

Blood Knot, People are Living There, The Road to Mecca, and My Children, My Africa were chosen in order to examine Fugard's use of space over the span of his career as well as over the breadth of his subjects. If the meaning of the spatial images from the earliest play is compared to the use of space in the relatively recent My Children, My Africa, 
similar patterns are disclosed. Fugard has continued to limit and control his spatial images to suggest similar meanings from play to play -- meanings of safety, frightening danger, and hopeful freedom.

The same continuity is found again when the plays are investigated according to topic. The struggle of the "coloured" race to be able to risk haven to find freedom from danger is the same struggle experienced by the "poor whites" of Fugard's plays. The reality of South African society is damaging to all the races involved, and Fugard uses the same means (spatial images) to communicate this same message from play to play.

The message communicated by the spaces of Fugard's plays stays consistent with what Fugard expresses in the privacy of his Notebooks. Remember what he wrote of his experience in the train ("All that is good and bad--and worse than bad, rotten and wrong. . ."). South Africa, Fugard's beloved country, is filled with danger, rottenness, and fear. But there is still the good--the hope of a better day and a peaceful land. A land free in all ways--free for the blacks, free for the "coloureds," and then truly free for the whites. Ideally, the recognition of the spaces in Fugard's work should be actively, and knowingly, articulated in any production of his plays. Drama is meant to be done, and such doing must involve space. The director, designer, and even the actor of a Fugard play must attend to the spaces of the 
play and the meaning they communicate. The spatial images and tensions in these four plays are integral to the meaning and should be enhanced through production. Fugard's plays should always begin as an "evocation of place." 


\section{A SELECTED BIBLIOGRAPHY}

Burke, Kenneth. 1967. The Philosophy of Literary Form. 2nd Ed. Baton Rouge: Louisiana State UP.

Elam, Keir. 1980. The Semiotics of Theatre and Drama. New York: Methuen.

Fugard, Athol. 1963. Blood Knot. Johannesburg: Simondium; New York: Samuel French.

-- Boesman and Lena. 1969. Cape Town, South Africa: Buren; New York: Samuel French. Revised 1971.

--. People are Living There. 1970. n.p.: Oxford University Press; New York: Samuel French.

--. Hello and Goodbye. 1971. Cape Town: Balkema; New York: Samuel French.

--. A Lesson From Aloes. 1981. Oxford: Oxford University Press; New York: Samuel French.

--. "MASTER HAROLD". . and the boys. 1982. New York: Knopf; New York: Samuel French.

--. The Road to Mecca. 1985. London: Faber and Faber; New York: Theatre Communication Group.

--. My Children, My Africa. 1990. London: Faber and Faber; New York: Samuel French.

--. Notebooks. 1983. Johannesburg: Donker; London: Faber and Faber.

Fugard, Athol and John Kani, Winston Ntshona. 1986. Statements: Sizwe Bansi is Dead, The Island and Statements After an Arrest Under the Immorality Act. n.p.: Oxford University Press; New York: Theatre Communication Group.

Gray, Stephen, ed. 1991. File on Fugard. Writer-Files. London: Methuen Drama. 
Guerin, wilfred L., et al. 1979. A Handbook of Critical Approaches. 2nd Ed. New York: Harper \& Row.

Hall, Edward T. 1959. The Silent Language. Garden City: Doubleday \& Company.

Ha11, Lawrence Sargent, ed. 1965. A Grammar of Literary Criticism: Essays in Definition of Vocabulary, Concepts, and Aims. New York: Macmillan.

Helbo, Andre. 1987. Theory of Performing Arts. Philadelphia: Benjamins.

Henry, William A. III. 1987. "Yearning for Ritual Pieties". Rev. of The Road to Mecca. Time 15 June: 70 .

Hurley, Joseph. 1990. "John Kani Plays a Teacher Caught in the Crossfire". Theatre Week. 15 January: 25.

Langer, Susanne K. 1953. Feeling and Form. New York: Charles Scribners Sons.

McCarthy, Mary. 1961. "Settling the Colonel's Hash." A Grammar of Literary Criticism. 1965. Ed. Lawrence Sargent Hall. New York: MacMillan: 340-49.

Meyers, Gail E. and Michele Tolela Myers. 1980. The Dynamics of Human Communication. New York: McGraw-Hill Book Company.

Schorer, Mark. 1972. "The World of Sinclair Lewis." The Critic as Artist: Essays on Books 1920-1979. Ed. Gilbert A. Harrison. New York: Liverwright: 299-304.

Verderber, Rudolph and Kathleen Verderber. 1989. Inter-Act. Belmont: Wadsworth Publishing Company.

Walder, Dennis. 1985. Athol Fugard. Grove Press Modern Dramatists New York: Grove Press.

Whalley, George. 1953. "From Symbol and Myth." A Grammar of Literary Criticism. 1965. Ed. Lawrence Sargent Hall. New York: MacMillan: 349-356.

wilson, Glenn. 1985. The Psychology of the Performing Arts. New York: st. Martin's Press. 